THEMATIC SPACE: SOCIAL PROTECTION IN CONTEMPORARY CAPITALISM:

COUNTER-REFORMS AND REGRESSION OF SOCIAL RIGHTS

\title{
Capital accumulation, crisis, and labor market in modern Brazil
}

\section{Gustavo Mello ${ }^{1}$}

https://orcid.org/0000-0002-4281-995X

Mauricio de Souza Sabadini ${ }^{1}$

https://orcid.org/0000-0002-8719-3065
Henrique Braga ${ }^{2}$

https://orcid.org/0000-0002-4505-290X

\footnotetext{
${ }^{1}$ Universidade Federal do Espírito Santo, Departamento de Economia, Programa de Pós-Graduação em Política Social, Vitória, ES, Brazil

${ }^{2}$ Universidade Federal do Espírito Santo, Departamento de Economia, Vitória, ES, Brazil
}

\section{Capital accumulation, crisis, and labor market in modern Brazil}

Abstract: This article presents the recent changes in the Brazilian labor market, resulting from the recessionary dynamics of the world capitalist economy of the last decades manifested since the 2007-2008 crisis. It observes the insertion of Brazil in the global capitalist economy and the foundations supporting the processes of reproduction of capital, analyzing some indicators of the labor market related to the labor-power employment, wage, rates of formalization and turnover, in light of central tendencies and determinations of today's process of expanded reproduction of capital. The study contributes to clarify phenomena such as the tendency to identify formal and informal work, the reconstitution of the industrial reserve army, wage repression and intensification of labor, which are promoted by the ongoing "reforms" in Brazil.

Keywords: Capital accumulation. Economic crisis. Brazilian labor market.

Submitted on June 1, 2018. Approved on September 18, 2018. Reviewed on December 10, 2018.

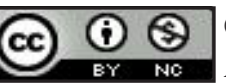

(C) The Author(s). 2019 Open Access This article is distributed under the terms of the Creative Commons Attribution-NonCommercial 4.0 International License (http://creativecommons.org/licenses/by-nc/4.0/), which permits use, distribution, and reproduction in any medium, since it's for non-commercial purposes, and provided you give appropriate credit to the original author(s) and the source, provide a link to the Creative Commons license, and indicate if changes were made. 


\section{Introduction}

The official narrative was bringing back the myth of the Brasil Potência [Powerful Brazil]. As with all ideologies, it was a mistake based on superficialities, which echoed in the international media (an example is the case of the magazine The Economist (2009), showing the Christ the Redeemer in Rio de Janeiro, taking off). After all, the average annual growth rate of the Gross Domestic Product (GDP) in the $2000 \mathrm{~s}$ was more than twice that of the $1980 \mathrm{~s}$, (3.6\% and $1.7 \%$ respectively), and higher than the GDP in the 1990s, of $2.6 \%$ (albeit much lower than that of the 1950s, 1960s and 1970s, respectively of $7.4 \%$, $6.2 \%$, and $8.7 \%$ ). Therefore, the results in the late $2000 \mathrm{~s}$ were inspiring, but only part of the job was done. When GDP is analyzed uncritically, it is an indicator useful to produce myths rather than to reflect the reality, as this article is about to show.

In this positive context - considering aspects such as the increase in formal employment rates, reduction in unemployment, raise in the minimum wage and growth in real average income, increase of wages participation in GDP, increase of state expenditures with social policies as well as more credit for consumption and production - the decrepit developmentalism was revived, and many welcomed the long-awaited structuring of the Brazilian labor market. Nevertheless, after the economic crisis that occurred at the end of 2014, this positive scenario seems now very distant. Analytical errors separating these two realities show the need to conceptually apprehend the recent historical process of Brazil.

In short, this article contextualizes some of the recent changes in the Brazilian labor market, based on the recessive dynamics of the world capitalist economy over the last decades, manifested especially since the 2007-2008 crisis. We believe that this crisis stems from some others that occurred in previous decades on a larger scale and with direct effects both on the periphery and at the center of the world's capitalist system.

The first assumption is that the movements observed since the 1990s in Brazil (a period of consolidation of neoliberal politics, regression of social and labor rights, intensification of austerity policies) were expressions of atrophied dynamics of capitalist accumulation. However obvious this may seem, at least for those who study the method of the critique of political economy, this path paved the way for the understanding of the movements that the policies implemented - and the consequent qualitative and quantitative changes - made in the Brazilian labor market. We believe that this relationship alone has the power to unmask and make it evident that the Brazilian labor market is unstructured in its origin and development. It carries determinations that go back to slavery, always manifested in informality, inequality, heterogeneity, and precariousness, symbols of peripheral and dependent capitalism.

The scope of this study is outlined by the recent indicators of the labor market, with particular attention to the recent Brazilian economic crisis. The crisis was marked, among other aspects, by a brutal fall in the GDP, more than $9 \%$ between the second half of 2013 and the first half of 2017 , and by a sharp increase in unemployment, which jumped from $6 \%$ in early 2015 to more than $13 \%$ by the end of 2016 . Despite strong official propaganda, the much-publicized economic recovery is far from consolidating, since the structural determinants - both crisis and the little performance of the Brazilian economy in the last decades - were not even remotely addressed. On the contrary, the neoliberal hysteria of recent years tend to aggravate this situation with its overwhelming "reformism", aiming, as argued in this work, to guarantee and channel resources to remunerate financial investors, to rebuild the Brazilian industrial reserve army, to discipline, and lowering the costs of the laborpower, as well as opening up new fields of activity to the private sector and transferring the state assets to private businesses at low prices.

Constitutional Amendment 95 is one of many pieces of legislation to be observed based on the context above. It freezes and determines narrow limits to the scarce primary expenditures of the federal government. Others are the outsourcing law (liberates and gives new impetus to this practice that results in evasion of labor policies and the tax system); the labor "reform" (eliminates a whole set of rights, legalizes intermittent labor, disrupts unions, establishes indemnity ceilings in case of labor damages, subordinates the law to the agreement between employer and employee, and therefore contributes to eliminate the boundaries between formal and informal work); and the attempts to approve the social security reform (that proposes elimination of rights, termination of the right to retire based on the length of contribution to the public pension system, the rise in the minimum retirement age, a sharp increase in the minimum length of contribution to the system for eligibility purpose, reduction in the payments, prohibition of accumulation of benefits, and other aspects) (Marques \& Ugino, 2017)1.

After this introduction, the article is organized with a second section that describes some notable characteristics of the Brazilian labor market in recent years. The third part presents, in general lines, the contextual and structural determinants of the Brazilian economy in the last decades, considering basic 
tendencies of capital accumulation. The discussions of the previous sections subsidize the fourth part of the article, which seeks to apprehend the nature and current configuration of the formal labor market in order to reveal the meaning of the current reforms proposed for the labor market, particularly the labor reform approved in 2017. Finally, the last section is dedicated to present some final considerations.

\section{Recent trends in the Brazilian labor market}

The Brazilian labor market may be considered an example of the type of labor relations found in any nation playing a peripheral role in the international division of labor in a dependent way. The forms of labor in the country are connected to relations of favor and treatment with the slave - characteristic inherited of the colonial times (Schwarz, 2012, pp. 10-31) - with the formal and real subsumption of labor to capital. This is an outcome of the unequal and combined development of the world capitalist market (Oliveira, 2003). In our point of view, and different from what is commonly advocated, these elements show that the Brazilian labor market has always been flexible and unstructured.

The notion of structured and unstructured labor market goes back to the already weak sectorial associations, which consider the formal and informal work, for example, as isolated segments of the capitalist reproduction cycle (M-C-M'). This current point of view, contested by vast literature (Lautier, 2004; Soares, 2008), may be considered is fragmented and full of weaknesses if one intends to build an expanded vision of the total functions performed by the workers in the general cycle.

According to Vargas (2015), based on data from the Pesquisa Nacional por Amostra de Domicílios [National Household Sample Survey] (PNAD) of the Instituto Brasileiro de Geografia e Estatística [Brazilian Institute of Geography and Statistics], the percentage of informal labor in the Brazilian economy was significant at the early 1980s. These figures consider employees without a formal contract, selfemployed workers and unpaid workers. In 1981, informal labor represented 59.5\% of the population of workers and $41.9 \%$ of the total employment. In 1984 these percentages rose to $61.8 \%$ and $45.1 \%$, respectively, and then fell in 1989 to $56.8 \%$ and $40.7 \%$, respectively. In the 1990 s, in a context of increasing unemployment, this situation was aggravated, and informal labor, went from $59 \%$ of the population of workers in 1992 to $60.7 \%$ in 1999 (Vargas, 2015). It should be emphasized, therefore, that informality should not be treated as an anomaly that is only associated with a greater or lesser level of economic activity, or with a larger or smaller regulation, although these factors may contribute to the increase or decrease in magnitude. Marx (1996b), putting the process of capitalist accumulation as a decisive factor for the emergence of relative surplus population, indicated that part of this population (the stagnant), is identified to a part of the active labor army, but with extremely irregular employment. Hence it furnishes to capital an inexhaustible reservoir of disposable labor power. Its conditions of life sink below the average normal level of the working class; this makes it at once the broad basis of special branches of capitalist exploitation (Marx, 1996b, p. 272).

If there is, on the one hand, an industrial reserve army, on the other hand, there is a permanent industrial active army, with particularities and specific characteristics, that have changed since the period analyzed by Marx, to the present day.

Regarding the labor contracts, from the early 2000s until the outbreak of the Brazilian economic crisis, official statistics indicate an improvement in the formal indicators of the labor market. This is usually appointed as a favorable moment for the Brazilian working population since these formal labor contracts would guarantee certain stability in labor relations. As can be seen in Chart 1, according to the Instituto Brasileiro de Geografia e Estatística's (IBGE, n.d.) Monthly Employment Survey, formal contracts jumped from $44.2 \%$ in 2003 to $54.7 \%$ in 2016 . As for informal labor, it totaled $40.6 \%$ of the employed population in the country in 2003 and decreased to $32.6 \%$ in 2016 .

Also, between 2003 and 2011 the unemployment rate fell from $12.4 \%$ to $6 \%$, reaching a minimum of 4.3\% in December 2014 (thereafter, there was a sharp increase in the number of unemployed, reaching a peak of $13.7 \%$ in January 2017) according to the continuous PNAD (IBGE, 2017). The share of wages in GDP, which was $30.7 \%$ in 2004, increased to $34.6 \%$ in 2014. Between 2003 and 2015, total real average income increased by $52.7 \%$ (Sabadini, Mello, \& Braga, 2018). According to the Relação Anual de Informações Sociais [Annual Social Information Report] (RAIS), between 2003 and 2013, the average wage registered a real growth of $30.6 \%$, or a growth of $2.7 \%$ per annum above inflation (Campos, 2016, p. 96) ${ }^{2}$. 


\section{Chart 1 - Average percentage of the working population in Brazil (2003-2016)}

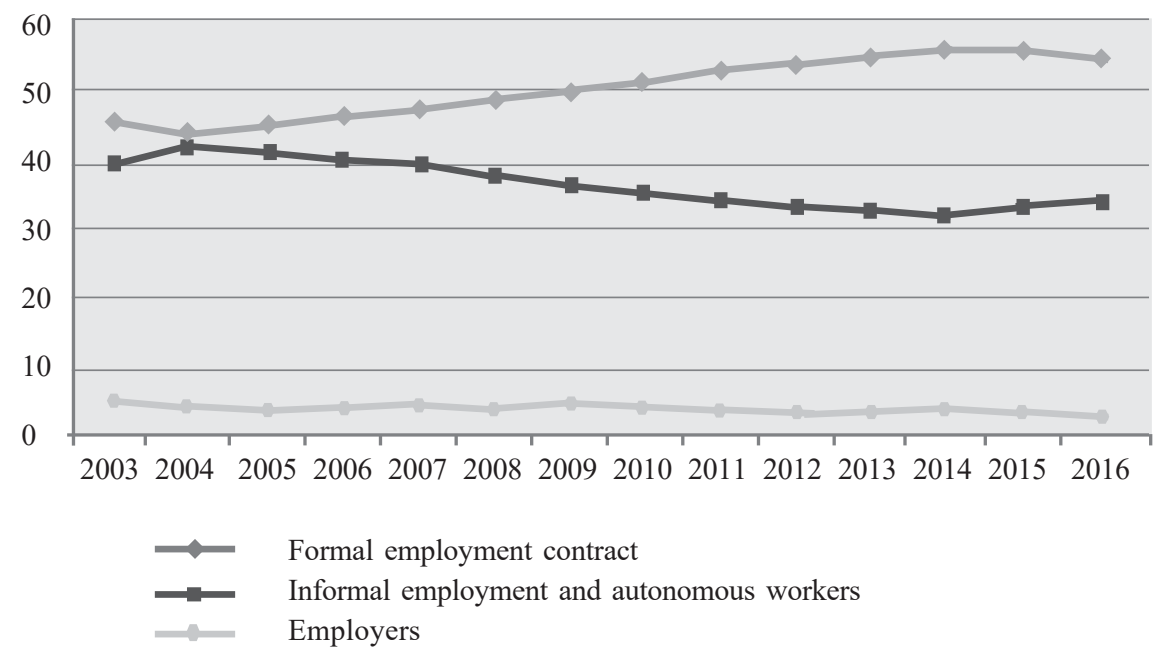

Source: Elaborated by the authors based on IBGE's (n.d.) Monthly Employment Survey.

\section{Structural and contextual conditioning elements of the current Brazilian economy dynamic}

The period observed in this work is an interesting moment in the Brazilian economy. The process of Brazilian industrialization throughout much of the twentieth century, full of vicissitudes, was abruptly interrupted by the debt crisis that followed Paul Volcker's interest shock. In this context, the weaknesses of the Brazilian economy expressed in the growing dependence on the volatile capitals of the world market, and the inability of endogenous technology production, came into view.

Faced with this virtual insolvency, the search for the scarce funds of multilateral organizations was conditioned, in practice, to a repositioning of the Brazilian economy in the world market: it was mainly a matter of strengthening its specialization in the production of commodities, and of consolidating the country as platform of financial valorization (Paulani, 2016, p. 210). This repositioning demanded measures such as the securitization of state debt, privatization, austerity policies, incentives to develop domestic financial markets (with strong presence of pension funds related to state-owned companies and and by the Fundo de Garantia do Tempo de Serviço [Length of Service Guarantee Fund] (FGTS), i.e., at the expense of the formal employment) and the eventual adoption of the so-called economic tripod (maintenance of primary surpluses, a regime of inflation targets guaranteed by exorbitant real interest rates, and a fluctuating exchange system, notably overvalued). It was imperative to guarantee security, calculability, and above all to generate foreign exchange to remunerate the over-accumulated capital on a global scale, always eager for financial income (Sampaio Júnior, 2018).

The outcomes of this dynamic are well known, particularly the degradation of a large part of the Brazilian industrial park and the maintenance of very low rates of accumulation, which is inversely proportional to unemployment rates (Sampaio, 2013). The exception to this rule was the years between 2003 and 2012, specially because of the increase of the commodity prices, under the effect of the immense demand from China. This fact opened the possibility to increase the minimum wage ${ }^{3}$, as well as for the expansion of focalized cash transfer policies ${ }^{4}$, and the attempt to force the economic development using the expansion of credit for consumption and production ${ }^{5}$.

According to Marqueti, Hoff, and Miebach (2016), between 2002 and 2007 there was an increase in the average rate of profit ${ }^{6}$, which is the main incentive of the capitalist production regarding competition (Marx, 1996, p. 252), from $26 \%$ to $32 \%$ and an increase in investment rates, from $16.6 \%$ in 2003 to $18 \%$ in 2007 . Nevertheless, the authors (Marqueti et al., 2016) note that in 2007 the net profit rate started to fall, and with some delay, the rate of accumulation follows this tendency. In that same year, private indebtedness accelerates, reaching extremely high levels (Rezende, 2016).

For Marqueti et al. (2016), the compression of profit rates was related to the wage increase in real terms, and not as a consequence of a more or less generalized increase in the organic composition of capital. From 2007 to 2014, the average rate of wage increase in real terms was higher than the rates of labor productivity. 
It is not surprising, therefore, that the share of net profit in the national income fell from $40.8 \%$ in 2003 to $32.9 \%$ in 2014 (IBGE, 2017), pari passu to a reduction of the average rate of profit ( $22 \%$ in 2014), which the authors (Marqueti et al., 2016) show to be a decrease of more than 30\% compared to 2007.

The explanation for this correlation lies, according to Marx (1996), in the effects of wage increase in an ascending phase of the economic cycle, when the organic composition of capital is relatively constant. As rising labor costs begin to constrain profitability, the capital works to rebuild the industrial reserve army, lower wages, intensify labor, which implies, nowadays, in eliminating labor and social security rights, for example. In short, it is the old extraction of surplus value, in its absolute form.

In the context observed in this study, marked by the 2007 global economic crisis expressed by the bursting of the North American real estate bubble, the Brazilian economic collapse took a little longer to be felt, due to the mobilization of a set of countercyclical measures of the state, made possible by the relative success of the previous years. Highlights include the billions of dollars spent on the federal housing program (Minha Casa, Minha Vida), the national growth acceleration program (Programa de Aceleração do Crescimento [PAC]), and the program to support investments (Programa de Sustentação do Investimento). Other state measures were the amazing amounts of subsidized credit provided by the Banco Nacional de Desenvolvimento Econômico e Social [National Bank for Economic and Social Development] (BNDES), the vigorous investment by state-owned companies (led by Petrobras), and the price control on strategic inputs, particularly fuel and electricity, together with tax exemptions (ranging from $\mathrm{R} \$ 3.6$ billion to $\mathrm{R} \$ 100.6$ billion between 2011 and 2014).

Despite these measures, the rate of utilization of productive capacity fell sharply from 2011. By the third quarter of 2013, the rate of gross fixed capital formation fell on a downward trajectory, falling drastically in the first quarter of 2014 (Rossi \& Mello, 2017). Faced with these trends, reinforced by the recessionary shock produced by the federal government in early 2015 articulating interest increases; drop in state spending; rise in controlled prices and exchange devaluation (Rossi \& Mello, 2017), the Brazilian economy went into depression. Thus, the errors and limitations of the countercyclical state measures were revealed, which only reflect and reinforce the miserable conditions of production and appropriation of capitalist wealth in Brazil, especially in the form of relative surplus value, which presupposes a thriving and diversified industry, or else the ability to extract surplus value produced elsewhere through patents and all sorts of title deeds and debt.

\section{Labor reform and impacts in the formal labor market}

If, on the one hand, there is a recent trend toward the creation of formal jobs, on the other hand, not only in Brazil, but worldwide, they are short-term, part-time, or fixed-term job positions. All over Europe, temporary and partial employment contracts are frequent. Between 2007 and 2012, an average of $14.4 \%$ of all workers was in temporary jobs and $19.3 \%$ were part-time workers. In 2016, according to Eurostat data ${ }^{7}, 21.6 \%$ of total employment for the population aged 15-64 was part-time work, while $13.3 \%$ were temporary jobs. The temporary contracts offer less social guarantees and lower pay. As an outcome of the capitalist dynamics in crisis, these types of contracts are increasing in several capitalist countries, following a trend of reduction of variable capital costs, based on the flexibilization in labor legislation, in an attempt to reactivate the dynamics of capitalist accumulation, with a significant setback for workers.

In Brazil, according to the statistics available currently, these types of contracts are less frequent. However, this situation may change in the next years, as suggested by the studies of the Departamento Intersindical de Estatística e Estudo Socioeconômicos [Inter-Union Department of Statistics and Socioeconomic Studies] (DIEESE, 2017d, p. 6), pointing out that Law 13429 expands the possibilities for companies to offer temporary work positions, which may reinforce the connection between temporary work and outsourcing. In any case, according to DIEESE (2017c), the temporary work as provided by Law 6019 of 1974 represented a low percentage of the formal labor market, $1.8 \%$ in $1995,2.4 \%$ in 2005, and $1.0 \%$ in 2015.

This information was corroborated by Krein, Abílio, Freitas, Borsari, and Cruz (2018), who showed that the temporary employment registered at RAIS was only $0.13 \%$ of the job positions on December 31 , 2016 (which is similar to the percentage observed in $2002-0.40 \%$ - as presented in Table 1. For Krein et al. $(2018$, p. 99) the fact that the indeterminate employment in Brazil is sufficiently flexible and companies are free to terminate the contract at any time, explains the low presence of atypical [temporary and fixed term] forms of contracting. It should be noted that contracts guided by the Consolidação das Leis do Trabalho [Brazilian Consolidation of Labor Laws] (CLT), which is the type of contract that can be called "formal," were $80 \%$ of the employment contracts in 2014 and 2016. 
Table 1 - Employment contracts on December 31, per type of contract

\begin{tabular}{l|r|r|r|r|r|r}
\hline \multirow{2}{*}{$\begin{array}{l}\text { Type of employment } \\
\text { contract }\end{array}$} & \multicolumn{2}{|c|}{2002} & \multicolumn{2}{c|}{2014} & \multicolumn{2}{c}{2016} \\
\cline { 2 - 7 } & \multicolumn{1}{|c|}{ Quant. } & \multicolumn{1}{c}{$\%$} & \multicolumn{1}{c}{ Quant. } & $\%$ & Quant. & $\%$ \\
\hline \multirow{2}{*}{ Regular, according to CLT } & $21,758,316$ & 75.89 & $39,186,985$ & 79.84 & $36,232,407$ & 79.30 \\
Government employment (tenured) & $5,263,383$ & 18.36 & $7,768,118$ & 15.68 & $7,641,533$ & 16.72 \\
Government employment (not tenured) & $1,099,116$ & 3.83 & $1,241,009$ & 2.76 & 949,913 & 2.08 \\
Temporary & 114,092 & 0.40 & 71,454 & 0.16 & 58,022 & 0.13 \\
Autonomous service provider & 183,737 & 0.64 & 156,502 & 0.39 & 109,409 & 0.24 \\
Fixed term, according to CLT & 195,044 & 0.68 & 380,920 & 0.78 & 348,201 & 0.76 \\
Director & 11,535 & 0.04 & 18,496 & 0.05 & 16,123 & 0.04 \\
Special government employment & 44,981 & 0.16 & 386,736 & 0.70 & 335,772 & 0.73 \\
\hline Total & $28,670,204$ & 100 & $49,210,220$ & 100 & $45,691,380$ & 100 \\
\hline
\end{tabular}

Source: RAIS, Ministério do Trabalho e Emprego [Brazilian Ministry of Labor and Employment] (MTE). In Krein et al. (2018, p. 99).

The sum of these atypical employment contracts (temporary, autonomous, non-tenured government employment, fixed-term and special government employment) is low, and it has reduced over the years: $5.71 \%$ in $2002,4.79 \%$ in 2014, and 3.94\% in 2016. Despite different databases, it is possible to observe these forms of contracting in European countries reach higher percentages.

What are the possible conclusions considering all the information above? In addition to the already flexible nature of the Brazilian labor market, there is still a considerable margin for the use of these forms of employment in the country. The fact that they are more vulnerable forms - from the point of view of workers' rights - they express an advance of predatory capital accumulation based on more flexible and unstable work, which is, again, at the core of the 2017 labor reform.

Perhaps, more important than increasing the plasticity of the labor-power, the 2017 reform is supposed to hinder the workers' bargaining capacity, as well as to put at risk their gains through Labor Justice, which in some cases has led to costs and insecurity for the capital (Marques \& Ugino, 2017) ${ }^{8}$. In this sense, supposing a pseudo-equality between workers and capitalists, the reform disregards the collective agreements, subordinates the legislation to the negotiation between employers and employees, and exposes the latter to the risk of bearing all the expenses arising from a legal dispute regarding the employment contract. Also, it establishes a maximum limit on labor indemnities, proportional to the salary of the worker in a legal dispute ${ }^{9}$. Thus, the number of labor claims and severance pay tends to decline sharply.

Regarding the current morphology of formal work, and considering the research works methodological differences, the information disclosed by labor agencies and the media indicate a distinct picture regarding temporary work in Brazil. A study by the International Confederation of Private Employment Agencies (Ciett), published in 2012 with data from 2010 on so-called agency workers (temporary workers with contracts with work agencies), indicates that Brazil is the third largest contractor of agency workers in the world, with an average of 965,000 daily contracts. The first country in this ranking is the United States, with approximately 2.58 million workers, followed by South Africa, with 967,000. According to this study, "together, the USA, South Africa, and Brazil account for $44 \%$ of all agency workers assigned worldwide" (International Confederation of Private Employment Agencies, 2012, p. 24).

Regarding part-time work, the data provided by Reis and Costa (2016) indicate a high percentage of these contracts in the Brazilian labor market. According to them, the total number of part-time workers (with or without employment contracts) from 16 to 80 years of age with a workload of 10 hours or more was $13.4 \%$ in 2014. This working day was implemented in the country in 1998 by Provisional Measure 1709/98 and was amended in 2001 by a new provisional measure. Another important fact is that $31 \%$ of the workers without a formal contract are temporary workers, while the percentage of part-time workers among those with formal employment contract drops to $5.6 \%$. This means that part-time work is more frequent among workers in informal labor relationships. In this way, most of the part-time working agreements are not registered, which may contribute to distorting the total number of part-time workers.

With the constant and recent changes in the labor market, other forms of temporary contracts were created based on specific legal rules, different from the typical temporary work. Examples of these contracts are the internships and the intermittent work (DIEESE, 2017b), the latter is similar to the British zero-hour 
contract. These examples are clear indications of a search for new forms of capital accumulation by mobilizing an industrial reserve army, available in abundance, and, when necessary, using it a lower remuneration, hiring, and dismissal costs. In addition to the clear reinforcement of relationships of favor, this context tends to increase the flexibility of the labor structure, especially with the approval of other measures such as the stimulus to outsourcing, which, according to Galvão, Krein, Biavaschi, and Teixeira (2017, p. 66), means to legalize the establishment of a new logic of subordination, management, and control of the labor-power, which can be generalized by various sectors of the economy.

Therefore, what is the type of formal work that Brazil is creating? Fixed-term work and formal work, considering all their characteristics, must be taken into account in order to understand this new and even more precarious configuration of work in the country ${ }^{10}$. Table 2 inspires important reflections that may help, if not answer, at least better qualify the directions proposed in this article.

Table 2 - Length of employment of formal workers dismissed in Brazil, 2000, 2005, 2009 (\%)

\begin{tabular}{|c|c|c|c|c|c|c|c|c|c|c|}
\hline Year & Cause of dismissal & $\begin{array}{c}\text { Up to } \\
2.9 \\
\text { months }\end{array}$ & $\begin{array}{c}\text { From } 3 \\
\text { to } 5.9 \\
\text { months }\end{array}$ & $\begin{array}{c}\text { From } 6 \\
\text { to } 11.9 \\
\text { months }\end{array}$ & $\begin{array}{c}\text { From } 12 \\
\text { to } 23.9 \\
\text { months }\end{array}$ & $\begin{array}{c}\text { From } 24 \\
\text { to } 35.9 \\
\text { months }\end{array}$ & $\begin{array}{c}\text { From } 36 \\
\text { to } 59.9 \\
\text { months }\end{array}$ & $\begin{array}{c}\text { From } 60 \\
\text { to } 119.9 \\
\text { months }\end{array}$ & $\begin{array}{c}120 \\
\text { or more } \\
\text { months }\end{array}$ & Total \\
\hline 2000 & $\begin{array}{l}\text { Termination of the } \\
\text { employment contract* }\end{array}$ & 69.0 & 16.8 & 7.8 & 1.8 & 0.8 & 0.9 & 1.2 & 0.5 & 100.0 \\
\hline 2005 & $\begin{array}{l}\text { Termination of the } \\
\text { employment contract }\end{array}$ & 68.9 & 15.7 & 10.5 & 2.0 & 0.4 & 0.5 & 0.3 & 0.4 & 100.0 \\
\hline 2009 & $\begin{array}{l}\text { Termination of the } \\
\text { employment contract }\end{array}$ & 71.2 & 10.9 & 11.1 & 2.9 & 0.8 & 0.8 & 0.5 & 0.4 & 100.0 \\
\hline
\end{tabular}

Source: DIEESE (2012, p. 90), based on MTE/RAIS. This is a copy of part of the table. * the variable termination of the employment contract also includes the temporary contracts (DIEESE, 2012, p. 89).

First, it is essential to clarify that the data were elaborated by the DIEESE based on RAIS. Therefore, the same source used to produce Table 1 . Second, the high percentage ( $70 \%$ on average), of the formal workers dismissed in the years shown in Table 2 remained in work for only up to 2.9 months, indicating the high degree of flexibility and turnover in the formal employment contracts. This represents what we call a trend towards nonformalization of the formal, in the labor market contracts. If,

... when the relevant changes in the Brazilian labor market are put in a context, it is possible to observe its historically unstructured nature and the tendency toward an even greater precariousness. as previously indicated, flexibilization is already a feature present in the Brazilian labor market, due both to the high degree of informality and the freedom around terminating contracts, the above data reinforce and make more evident the fact that fixed-term formal contracts have a minimal duration, also demonstrating the flexibility in the types of formal employment contracts.

In this sense, the advance of capital in the search for new forms of its reproduction encompasses both the roles of the industrial reserve army in the labor market - subjecting the market to the cycle of capital (Soares, 2008) - and, through informality, the mystified relations of flexibilization existing in the formal contracts. For this reason, unlike observed in the traditional reading, the dichotomous view of formal work as protected and informal work as unprotected is finished, if not entirely destroyed, it becomes extremely fragile, considering the data presented here. It is true that different from the informal workers, there are still significant and essential guarantees for those workers with formal employment contracts. However, it seems that the limit separating formal and informal workers are narrower in modern capitalism.

The practice of reducing costs and increasing profitability at the expense of social and labor rights in order to reactivate the dynamics of capitalist accumulation that was at risk in the face of the recent crises finds spaces of creation and appropriation of wealth. These spaces are manifested in increasing labor flexibility and 
in various reforms that have been in place worldwide, including Brazil. Other examples of this context are the adoption of the liberalization of outsourcing, the possibility of hiring professionals as if they were legal entities (a legal arrangement called Microempreendedores Individuais [Individual Micro-Entrepreneurs] (MEI), as well as new forms of employment contract known as "uberization") (Krein et al., 2018).

\section{Final considerations}

This article showed that the vicissitudes of the labor market and that the meanings of the current reforms, in particular the Labor Reform, are only intelligible in light of the global dynamics of capital accumulation and the fundamental tendencies of its expanded reproduction, in view of the specific way the Brazilian economy is inserted in the world market and its structural determinants, which gain momentum in the face of the economic crisis still in place in the country. In this context, neoliberal reforms, in progress since 1990, have been expanded and accelerated in the last two years.

Thus, when the relevant changes in the Brazilian labor market are put in a context, it is possible to observe its historically unstructured nature and the tendency toward an even greater precariousness. In general terms, the Brazilian labor market reflects the historical nature of the nation's social construction, due to the continuous renewal of the processes of production of inequality, heterogeneity, exploitation, and spoliation. It is a society in which the typical relations of its colonial past harmoniously combine with the relations of capitalism, producing a pattern of sui generis, peripheral and dependent capital accumulation.

At the same time, it is essential to recognize that the recent changes, which negatively impact on the life of the working population, point to a system of even more significant lack of protection in the social and labor context, as a consequence of the search for new forms of accumulation. In this way, these chances are set as an attempt to counteract the fall in the profit rates.

Finally, if this scenario leads to expect darker times, the critique of political economy - preventing the errors of the developmental nostalgia and reformism in general - may favor the struggle against the current fascist societal tendencies, given the social antagonisms that will certainly be aggravated.

\section{References}

Emenda Constitucional No. 95, de 15 de Dezembro de 2016, Diário Oficial da União [D.O.U] de 15.12.2016. Retrieved from http:// www.planalto.gov.br/ccivil_03/constituicao/emendas/emc/emc95.htm

Medida Provisória No. 1.709-1, de 3 de Setembro de 1998, Diário Oficial [D.O.] de 4.9.1998. Retrieved from http://www.planalto.gov.br/ cciviL_03/MPV/Antigas/1709-1.htm.

Campos, G. C. S. (2016). Evolução do emprego formal no Brasil (2003-2013). Carta Social e do Trabalho, 33, 93-98.

Departamento Intersindical de Estatística e Estudos Socioeconômicos. (2012). A situação do trabalho no Brasil na primeira década dos anos 2000. São Paulo, Brazil: Author.

Departamento Intersindical de Estatística e Estudos Socioeconômicos. (2017a). A reforma trabalhista e os impactos para as relações de trabalho no Brasil (Technical Note No. 178). São Paulo, Brazil: Author,

Departamento Intersindical de Estatística e Estudos Socioeconômicos. (2017b). Contrato de trabalho intermitente. São Paulo, Brazil: Author.

Departamento Intersindical de Estatística e Estudos Socioeconômicos. (2017c). Impactos da Lei 13.429 de 2017 (antigo PL 4.302/1998) para os trabalhadores: Contrato de trabalho temporário e terceirização (Technical Note No. 175). São Paulo, Brazil: Author.

Departamento Intersindical de Estatística e Estudos Socioeconômicos. (2017d). Relações de trabalho sem proteção: De volta ao periodo anterior a 1930? (Technical Note No. 179). São Paulo, Brazil: Author.

Fagnani, E. (2012). Piso de proteção social: O debate internacional e a experiência brasileira (Working Paper No. 203). Campinas, Brazil: Unicamp.

Fagnani, E. (2014). Política social e desigualdade: Projetos em disputa (Working Paper No. 238). Campinas, Brazil: Unicamp.

Alegretti, L. (2017, November 11). 'Se burlarem direitos sociais, vamos agir', diz procurador-geral do Trabalho. Folha de S. Paulo. Retrieved from http://www1.folha.uol.com.br/mercado/2017/11/1934630-se-burlarem-direitos-sociais-vamos-agir-diz-procurador-geral-do-trabalho.shtml Galvão, A., Krein, J. D., Biavaschi, M. B., \& Teixeira, M. O. (Orgs.). (2017.) Contribuição crítica à reforma trabalhista. Retrieved from https://www.ael.ifch.unicamp.br/pf-ael/public-files/noticias/arquivos/dossie_cesit_-_contribuicao_critica_a_reforma_trabalhista.2017.pdf Instituto Brasileiro de Geografia e Estatística. (n.d.). Pesquisa mensal de emprego [Database]. Retrieved from https://ww2.ibge.gov.br/ home/estatistica/indicadores/trabalhoerendimento/pme_nova/defaulttab_hist.shtm

Instituto Brasileiro de Geografia e Estatística. (2017). Pesquisa nacional por amostra de domicílios contínua: Algumas características da força de trabalho por cor ou raça. Retrieved from ftp://ftp.ibge.gov.br/Trabalho_e_Rendimento/Pesquisa_Nacional_por_Amostra 
_de_Domicilios_continua/Trimestral/Caracteristicas_da_forca_de_trabalho_por_cor_ou_raca/Algumas_caracteristicas_da_ forca_de_trabalho_por_cor_ou_raca_2016_04_trimestre.pdf

International Confederation of Private Employment Agencies. (2012). The agency work industry around the world: Economic report. Retrieved from http://www.weceurope.org/fileadmin/templates/ciett/docs/Stats/Ciett_econ_report_2012_final.pdf.

Krein, J. D., Abílio, L., Freitas, P., Borsari, P., \& Cruz. R. (2018). Flexibilização das relações de trabalho: Insegurança para os trabalhadores. In J. D. Krein, D. M. Gimenez, \& A. L. dos Santos (Orgs.), Dimensões críticas da reforma trabalhista no Brasil (pp. $95-$ 122). Campinas, Brazil: Curt Nimuendajú.

Lautier, B. (2004). L'économie informelle dans le tiers monde. Paris, France: La découverte.

Marques, R. M., \& Ugino, C. K. (2017). O Brasil é chamado à ordem. Argumentum, 9(3), 8-23.

Marquetti, A., Hoff, C., \& Miebach, A. (2016). Lucratividade e distribuição: A origem econômica da crise política brasileira. Retrieved from https://www.researchgate.net/publication/312191358_Lucratividade_e_Distribuicao_A_Origem_Economica_da_Crise_Politica_Brasileira

Marx, K. (1996a). O capital: crítica da economia política: Livro primeiro: O processo de produção do capital (Vol. 1, t. 1). São Paulo, Brazil: Nova Cultural.

Marx, K. (1996b). O capital: Crítica da economia política: Livro primeiro: O processo de produção do capital (Vol. 1, t. 2). São Paulo, Brazil: Nova Cultural.

Oliveira, F. de. (2003). Crítica à razão dualista. O ornitorrinco. São Paulo, Brazil: Boitempo.

Paulani, L. M. (2016). Modernity and capitalist progress in the periphery: The Brazilian case. European Journal of Social Theory, $19(2), 210-227$.

Reis, M., \& Costa, J. (2016). Jornada de trabalho parcial no Brasil. Mercado de Trabalho: conjuntura e análise, 22(61), 33-40.

Rezende, F. (2016). Financial fragility, instability and the Brazilian crisis: A Keynes-Minsky-Godley approach. Multidisciplinary Institute for Development and Strategies.

Rossi, P., \& Mello, G. (2017). Choque recessivo e a maior crise da história: A economia brasileira em marcha à ré. Retrieved from https://www.eco.unicamp.br/images/arquivos/NotaCecon1_Choque_recessivo_2.pdf

Sabadini, M. de S., Mello, G. M. de C., \& Braga, H. P. (2018). O mercado de trabalho brasileiro no período 1994-2016. Unpublished manuscript.

Sampaio, D. P. (2013). A desindustrialização em marcha no Brasil. Revista da Sociedade Brasileira de Economia Política, 34, $33-55$.

Sampaio Júnior, P. de A. (2018, September 10). Crise econômica mundial e tendências da divisão internacional do trabalho. Retrieved from http:/teoriaerevolucao.pstu.org.br/crise-economica-mundial-tendencias-divisao-internacional-do-trabalho/

Schwarz, R. (2012). Ao vencedor as batatas: Forma literária e processo social nos inícios do romance brasileiro. São Paulo, Brazil: 34. Soares, M. A. T. (2008). Trabalho informal: Da funcionalidade à subsunção ao capital. Vitória da Conquista, Brazil: UESB.

The Economist. (2009, November 14). Brazil takes off [Magazine cover]. Retrieved from https://www.economist.com/sites/default/ files/imagecache/200-width/20091114issuecovUS400.jpg

Vargas, J. (2015). A informalidade no mercado de trabalho: Um desafio institucional permanente para a economia brasileira. (Master's thesis, Federal University of Espírito Santo, Vitória, Brazil). Retrieved from http://dspace2.ufes.br/

\section{Notes}

1 It is worth adding a renewed wave of privatizations, with the billionaire plundering of assets of state-owned companies such as Petrobras; the authorization for private companies to command oil extraction in Brazilian pre-salt oil basins, the development of public-private partnerships and privatization of management in diverse areas, including those that had remained more or less preserved, such as state education and health. Also, it is important to remember the imminent sale of Eletrobras, the country's largest electricity generating and distributing company; the debt forgiveness granted to large economic groups, including debts formed from deliberated tax evasion practices; as a result of economic opening, and new incentives for transnational capital inflows, with a focus on markets that were once interdicted or impeded by legislation, such as the land market and the health area.

2 According to data from the continuous PNAD from IBGE analyzed by Sabadini, Mello, and Braga (2018), in 1995 the jobs that remunerated up to 1 minimum wage corresponded to $22 \%$ of the total, a percentage that rose to $29.3 \%$ in 2009 , falling to $25.6 \%$ in 2015 . The range of remuneration between 1 and 2 minimum wages shows a constant increase in the period, jumping from $20.4 \%$ in 1995 to $36.7 \%$ in 2015 . Between those years, occupations that paid between 2 and 5 minimum wages fell relatively modestly, going from $24.3 \%$ to $21.2 \%$, while the percentage of those earning more than 5 minimum wages fell sharply from $17 \%$ in 1995 to $8,3 \%$ in 2015 .

3 The minimum wage increased by approximately 70\%, in real terms, between 2003 and 2016. The minimum wage is at the base of the calculations for the Brazilian social security and social assistance systems. Therefore, its variation has a relevant and wide impact, particularly on the income of the poorest portions of the population.

4 The per capita Gasto Social Federal [Federal Social Expenses] (GSF) increased by about 60\% between 2004 and 2010 (Fagnani, 2014, p. 2).

5 Between 2004 and 2010, credit to individuals increased by 160\% and corporate credit to 83\% (Fagnani, 2012). According to Fagnani (2014, p. 2), the state-owned banks have launched an aggressive strategy of credit expansion, which almost doubled the credit between 2003 and 2010 (from $24 \%$ to $49 \%$ of the GDP). 
The calculation considered taxes and interest.

7 Data can be retrieved from https:/ec.europa.eu/eurostat/data/database

8 Capital that has such good reasons for denying the sufferings of the legions of workers that surround it, is in practice moved as much and as little by the sight of the coming degradation and final depopulation of the human race, as by the probable fall of the earth into the sun. In every stockjobbing swindle everyone knows that some time or other the crash must come, but everyone hopes that it may fall on the head of his neighbor, after he himself has caught the shower of gold and placed it in safety. Après moi le déluge! [After me, the flood] is the watchword of every capitalist and of every capitalist nation. Hence Capital is reckless of the health or length of life of the laborer, unless under compulsion from society. To the out-cry as to the physical and mental degradation, the premature death, the torture of over-work, it answers: Ought these to trouble us since they increase our profits? (Marx, 1996a, p. 383).

9 In an interview published in the newspaper Folha de S. Paulo (Alegretti, 2017), the Attorney-General of the Public Ministry of Labor, Ronaldo Fleury, emphasized that the legislation formally established that the physical and moral integrity of a well-paid worker is worth more than the integrity of the precarious worker. In addition, Fleury foreshadowed that, with the Labor Reform, there will be a very large demand for hiring on an intermittent working day. Moreover, with regard to the workers' remuneration, he said: the reform will create a mass of low-wage workers. As for the impacts on the negotiation dynamics between employers and employees, Fleury said: guess when there will be collective negotiation? Never.

10 Some changes in employment contracts based on fixed terms may be observed in DIEESE (2017a).

\section{Gustavo Mello}

gustavo.m.mello@ufes.br

Doctor of Sociology from Faculty of Philosophy, Languages, and Human Sciences of the Universidade de São Paulo (USP)

Assistant Professor at the Department of Economics and the Graduate Program in Social Policies of the Universidade Federal do Espírito Santo (UFES)

\section{Mauricio de Souza Sabadini}

mauricio.sabadini@ufes.br

Doctor of Economics from Université Paris 1 Panthéon-Sorbonne

Professor at the Department of Economics and the Graduate Program in Social Policies of the Universidade Federal do Espírito Santo (UFES)

\section{Henrique Braga}

henrique.p.braga@ufes.br

Doctor of Economic Sciences from Institute of Economics of the Universidade Estadual de Campinas (Unicamp)

Assistant Professor at the Department of Economics of the Universidade Federal do Espírito Santo (UFES)

\section{UFES}

Av. Fernando Ferrari, 514 - Goiabeiras

Vitória - Espírito Santo - Brazil

CEP: 29.075-910

Funding

Not applicable.

\section{Authors' contributions}

Charts and tables were elaborated by Maurício Sabadini and Gustavo Mello. The analysis was carried out by the three authors.
Consent for publication

Not applicable.

\section{Competing interests}

There are no competing interests.

Ethics approval and consent to participate

Not applicable. 